\title{
Chiral Redox-Active Isosceles Triangles
}

Siva Krishna Mohan Nalluri, ${ }^{\dagger}$ Zhichang Liu,${ }^{\dagger}$ Yilei Wu,${ }^{\dagger}$ Keith R. Hermann, ${ }^{\dagger}$ Avik Samanta, ${ }^{\dagger}$ Dong Jun Kim,${ }^{\dagger}$ Matthew D. Krzyaniak, ${ }^{\ddagger}$ Michael R. Wasielewski ${ }^{\ddagger}$ and J. Fraser Stoddart* ${ }^{\dagger}$

'Department of Chemistry, Northwestern University, 2145 Sheridan Road, Evanston, Illinois 60208-3113, USA

${ }^{t}$ Department of Chemistry, Argonne-Northwestern Solar Energy Research (ANSER) Center, Northwestern University, 2145 Sheridan Road, Evanston, Illinois 60208-3113, USA

*E-mail: stoddart@northwestern.edu

\section{SUPPORTING INFORMATION}

\section{Table of Contents}

Section A. Materials / General Methods / Instrumentation

Section B. Synthetic Protocols

Section C. NMR Spectroscopy

Section D. Crystallographic Characterization

Section E. Cycling Performance of the Batteries 


\section{Section A. Materials / General Methods / Instrumentation}

All chemicals and reagents were purchased from commercial suppliers (Aldrich or Fisher) and used without further purification. Compounds, symmetric triangular macrocycles ((-)-3NDI- $\boldsymbol{\Delta}^{1}$ and (-)-3PMDI- $\left.\Delta^{2}\right), 1,2$-cyclohexane-bis(naphthalene monoimide monoanhydride) $)^{3}(-)-2$ NIA, bis(cyclohexyl)naphthalenetetracarboxylic diimide ${ }^{4}$ (Ref-NDI) and bis(cyclohexyl)pyromellitic diimide $^{5}$ (Ref-PMDI) were prepared according to previous literature procedures. Cobaltocene $\left(\mathrm{CoCp}_{2}\right)$ was handled and stored in an argon Glovebox. While small amounts of $(R R)$-trans-1,2cyclohexanediamine were purchased from Aldrich Chemical Company, larger quantities of the pure enantiomers were obtained by resolving racemic trans-1,2-cyclohexanediamine with $L-(+)-$ tartaric acid, as described in the literature. ${ }^{6}$ Thin layer chromatography (TLC) was performed on silica gel 60 F254 (E. Merck). Column chromatography was carried out on silica gel 60F (Merck 9385, 0.040-0.063 mm). High-resolution mass spectra were measured on an Agilent 6210 Time of Flight (TOF) LC-MS, using an ESI source, coupled with Agilent 1100 HPLC stack, using direct infusion $(0.6 \mathrm{~mL} / \mathrm{min})$. UV/Vis absorption spectra were recorded using a UV-3600 Shimadzu spectrophotometer. Circular dichroism (CD) measurements were carried out on a Jasco J-815 spectrometer. Nuclear magnetic resonance (NMR) spectra were recorded on a Bruker Avance 600 and Varian P-Inova 500 spectrometers, with working frequencies of 500 and $600 \mathrm{MHz}$, respectively. Chemical shifts are reported in ppm relative to the signals corresponding to the residual non-deuterated solvents $\left(\mathrm{CDCl}_{3}: \delta 7.26 \mathrm{ppm}\right)$. Continuous-wave electron paramagnetic resonance (EPR) and electron-nuclear double resonance (ENDOR) spectra were acquired at Xband $(9.5 \mathrm{GHz})$ with a Bruker Elexsys E580 spectrometer, fitted with the DICE ENDOR accessory, an EN801 resonator, and an ENI A-500 RF power amplifier. Applied RF powers ranged from 200 to $400 \mathrm{~W}$ across the $7 \mathrm{MHz}$ scanned range, and the microwave power ranged from 2 to 
$20 \mathrm{~mW}$. EPR Spectra were recorded with $0.010 \mathrm{mT}$ modulation amplitude. The sample temperatures were controlled by a liquid $\mathrm{N}_{2}$ flow system. Samples were reduced using $\mathrm{CoCp}_{2}$ as the chemical reductant and loaded into $1.4 \mathrm{~mm}$ I.D. quartz tubes, which were sealed with epoxy resin in an argon-filled glovebox. A spline fit baseline correction was applied to the ENDOR spectra following integration. The EPR and the ENDOR spectra were fit in MATLAB ${ }^{7}$ using EasySpin v4.5.5. ${ }^{8}$

Cyclic Voltammetry (CV). The experiments were carried out at room temperature in Arpurged solutions of $\mathrm{CH}_{2} \mathrm{Cl}_{2}$ with a Gamry Multipurpose instrument (Reference 600) interfaced to a PC. All CV experiments were performed using a glassy carbon working electrode $\left(0.071 \mathrm{~cm}^{2}\right)$. The electrode surface was polished routinely with $0.05 \mu \mathrm{m}$ alumina-water slurry on a felt surface immediately before use. The counter electrode was a Pt coil and the reference electrode was an $\mathrm{Ag} / \mathrm{AgCl}$ electrode. The concentration of the sample and supporting electrolyte, tetrabutylammonium hexafluorophosphate $\left(\mathrm{TBAPF}_{6}\right)$, were $1.0 \mathrm{mM}$ and $0.1 \mathrm{M}$, respectively. The CV cell was dried in an oven immediately before use, and Ar was continually flushed through the cell as it was cooled down to room temperature to avoid condensation of water.

Quantum Mechanical Calculations. The geometries of the chiral asymmetric triangular macrocycles were initially relaxed using molecular mechanics with the MMFF94 force field, as implemented in the Avogadro 1.1.0 software. ${ }^{9}$ Geometries were subsequently relaxed using density functional theory (DFT), implemented in the TeraChem $1.5 \mathrm{~K}$ software. ${ }^{10}$ All DFT calculations made use of the B3LYP exchange-correlation functional with a split-valence double zeta basis set with added diffuse and polarization functions (6-31G*); all calculations on radical species were done using unrestricted DFT. Following geometry minimization in TeraChem $1.5 \mathrm{~K}$, geometries were submitted to QChem $4.0^{11}$ for further geometry optimization. 
Battery Fabrication. Organic electrodes were fabricated using the following procedure.

The active material, conductive acetylene black, and polyvinylidene fluoride (PVDF) binder (100 $\mathrm{mg}$ in total) were mixed in a ratio of 5:4:1 (50 wt $\%$ active material) by weight in $1 \mathrm{~mL}$ of $N$ methyl-2-pyrrolidone (NMP) which was stirred with a mechanical stirrer for 2 hours at room temperature and coated onto an aluminum foil substrate with a doctor blade set to a height of 15 $\mu \mathrm{m}$. Coatings were dried in a vacuum oven at $80{ }^{\circ} \mathrm{C}$ for 24 hours, then were cut into circular electrode discs with diameters of $11 \mathrm{~mm}$. After weighing the electrode discs, they were transferred into a glove box and assembled under an Argon atmosphere into half lithium-ion batteries using CR2032 coin cell hardware, with lithium foil as the counter electrode and a Celgard® 2400 separator and a total of $200 \mu \mathrm{L}$ of a $1 \mathrm{M}$ lithium hexafluorophosphate $\left(\mathrm{LiPF}_{6}\right)$ in a (1:1) ethylene carbonate and dimethyl carbonate electrolyte solution.

Electrochemical Characterizations. Galvanostatic charging/discharging of the batteries was monitored within a voltage window of $1.6-3.2 \mathrm{~V}$ (versus $\mathrm{Li} / \mathrm{Li}^{+}$) using (i) an MTI BST8-WA Battery Tester for applied currents lower than $1 \mathrm{~mA}$, and (ii) an MTI BST8-MA Battery Tester for applied currents higher than $1 \mathrm{~mA}$. Solid-state cyclic voltammograms (CVs) were recorded within the same voltage window on a Gamry Dual Cell CR2032 Battery Holder, connected to a Gamry Reference 600 potentiostat and interfaced to a PC. The scan rates were $0.05 \mathrm{mV} \cdot \mathrm{s}^{-1}$. All electrochemical testing was conducted at room temperature $\left(\sim 30^{\circ} \mathrm{C}\right)$. 


\section{Section B. Synthetic Protocols}<smiles>O=c1oc(=O)c2cc3c(=O)oc(=O)c3cc12</smiles>

PMDA

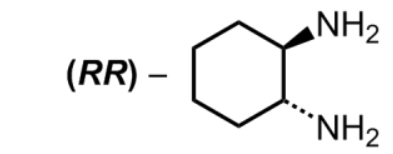

(i) $p-\mathrm{TsOH} / \mathrm{AcOH} / 2 \mathrm{~h}$ (ii) $\mathrm{Aq} \mathrm{NaHCO}_{3}$

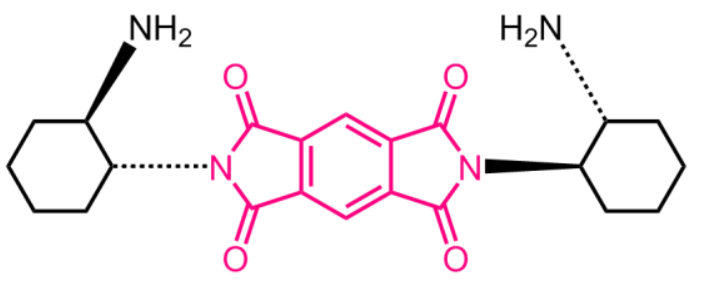

(-)-1PMDI-2 $\mathrm{NH}_{2}$

\section{Scheme S1. Synthesis of (-)-1PMDI-2 $\mathrm{NH}_{2}$}

(-)-1PMDI-2NH2. The synthetic protocol was adopted ${ }^{12,13}$ according to the literature procedure, except that a slightly modified procedure was used as follows. The compound (RR)-trans-1,2cyclohexanediamine $(1.14 \mathrm{~g}, 10.0 \mathrm{mmol})$ was added quickly in one portion to a vigorously stirred suspension of pyromellitic dianhydride (1.09 $\mathrm{g}, 5.0 \mathrm{mmol})$ and $p$-toluenesulfonic acid monohydrate $(1.90 \mathrm{~g}, 10.0 \mathrm{mmol})$ in glacial $\mathrm{AcOH}(25 \mathrm{~mL})$ at room temperature. The reaction mixture was stirred under reflux until a homogenous solution was obtained and the stirring was continued for an additional $2 \mathrm{~h}$, after which time the homogenous solution became transformed into a suspension. The reaction mixture was cooled down to room temperature and the solvent was removed under reduced pressure. The crude residue was purified by precipitation followed by filtration from $\mathrm{MeOH}-\mathrm{Et}_{2} \mathrm{O}$ to afford the ditosylate of (-)-1PMDI-2NH2 as a white solid. This ditosylate salt of (-)-1PMDI-2NH2 was taken up in $\mathrm{CH}_{2} \mathrm{Cl}_{2}(100 \mathrm{~mL})$ and a saturated $\mathrm{NaHCO}_{3}$ solution $(50 \mathrm{~mL})$ was added to this $\mathrm{CH}_{2} \mathrm{Cl}_{2}$ solution. The resulting solution was stirred overnight at room temperature. The organic layer was separated and the aqueous layer was extracted with $\mathrm{CH}_{2} \mathrm{Cl}_{2}(3 \times 50 \mathrm{~mL})$. The organic layers were combined, dried $\left(\mathrm{MgSO}_{4}\right)$ and concentrated under reduced pressure to afford pure (-)-1PMDI-2NH2 $(1.33 \mathrm{~g}, 3.24 \mathrm{mmol})$ in $65 \%$ overall yield as a white solid. ${ }^{1} \mathrm{H}$ NMR (500 MHz, $\left.\mathrm{CDCl}_{3}, 25{ }^{\circ} \mathrm{C}\right) \delta=8.24$ (s, 2H), $3.90-3.80$ (m, 2H), 3.39 (td, $J$ $=10.9,4.1 \mathrm{~Hz}, 2 \mathrm{H}), 2.28-2.10(\mathrm{~m}, 2 \mathrm{H}), 2.10-2.01(\mathrm{~m}, 2 \mathrm{H}), 1.91-1.72(\mathrm{~m}, 8 \mathrm{H}), 1.51-1.31$ $(\mathrm{m}, 4 \mathrm{H}), 1.30-1.11(\mathrm{~m}, 4 \mathrm{H}) .{ }^{13} \mathrm{C} \mathrm{NMR}\left(125 \mathrm{MHz}, \mathrm{CDCl}_{3}, 25{ }^{\circ} \mathrm{C}\right) \delta=166.9,137.2,118.3,59.1$, 51.0, 37.5, 29.5, 25.7, 25.2. ESI-MS $(\mathrm{m} / \mathrm{z})$ : calcd for $[M+\mathrm{H}]^{+}=411.20$; found: 411.20. 


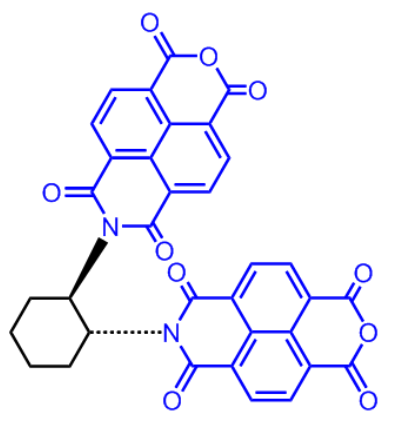

$(-)-2$ NIA

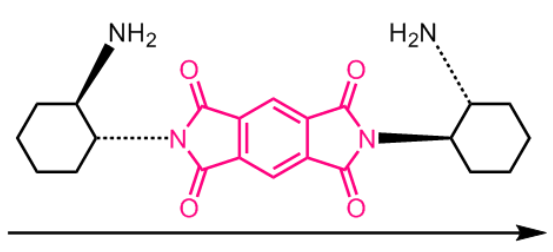

DMF / $130^{\circ} \mathrm{C} / 12 \mathrm{~h}$

$50 \%$

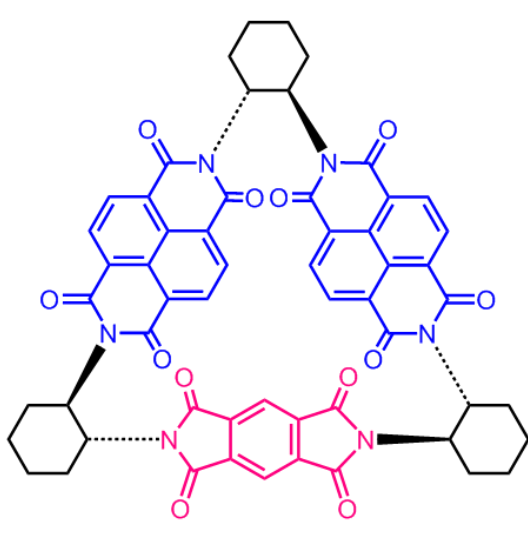

(-)-1PMDI-2NDI- $\Delta$

Scheme S2. Synthesis of (-)-1PMDI-2NDI- $\Delta$

(-)-1PMDI-2NDI-A. A warm suspension of (-)-1PMDI-2NH2 (697 mg, $1.7 \mathrm{mmol})$ in anhydrous

DMF (30 mL) was added quickly to a vigorously stirred homogenous solution of (-)-2NIA (1.05

g, $1.7 \mathrm{mmol})$ in anhydrous $\mathrm{DMF}(70 \mathrm{~mL})$ at $100{ }^{\circ} \mathrm{C}$ under $\mathrm{N}_{2}$. The resulting reaction mixture was stirred overnight at $130{ }^{\circ} \mathrm{C}$ under $\mathrm{N}_{2}$, after which the DMF was removed under reduced pressure ( $\sim 3$ mbar) at $60{ }^{\circ} \mathrm{C}$. The deep red residue was dissolved in $\mathrm{CH}_{2} \mathrm{Cl}_{2}$ and subjected to column chromatography $\left(\mathrm{SiO}_{2}: \mathrm{CH}_{2} \mathrm{Cl}_{2} / \mathrm{Me}_{2} \mathrm{CO}\right.$, gradient from 0-10\% $\left.\mathrm{Me}_{2} \mathrm{CO}\right)$ to afford pure (-)1PMDI-2NDI- $\Delta(0.84 \mathrm{~g}, 0.85 \mathrm{mmol})$ in $50 \%$ yield as an off-white solid. ${ }^{1} \mathrm{H}$ NMR (500 MHz, $\left.\mathrm{CDCl}_{3}, 25^{\circ} \mathrm{C}\right) \delta=8.60-8.48(\mathrm{~m}, 8 \mathrm{H}), 7.88(\mathrm{~s}, 2 \mathrm{H}), 6.31-6.16(\mathrm{~m}, 2 \mathrm{H}), 5.84(\mathrm{td}, J=11.7,3.7$ $\mathrm{Hz}, 2 \mathrm{H}), 5.45(\mathrm{td}, J=11.7,3.6 \mathrm{~Hz}, 2 \mathrm{H}), 2.60-2.46(\mathrm{~m}, 2 \mathrm{H}), 2.46-2.33(\mathrm{~m}, 2 \mathrm{H}), 2.21-2.09(\mathrm{~m}$, 2H), $2.07-1.83(\mathrm{~m}, 12 \mathrm{H}), 1.77-1.66(\mathrm{~m}, 2 \mathrm{H}), 1.66-1.52(\mathrm{~m}, 4 \mathrm{H}) .{ }^{13} \mathrm{C} \mathrm{NMR}(125 \mathrm{MHz}, \mathrm{CDCl} 3$, $\left.25^{\circ} \mathrm{C}\right) \delta=165.9,165.3,162.9,162.7,162.6,162.5,136.4,136.1,131.7,131.6,131.0,130.9,126.6$ 126.4, 126.2, 126.1, 125.9, 118.7, 54.1, 51.4, 31.2, 30.1, 29.7, 26.0, 25.6, 25.4. ESI-HRMS ( $\mathrm{m} / \mathrm{z})$ : calcd for $[M+\mathrm{H}]^{+}=989.2777$; found: 989.2779 . 
<smiles>O=c1oc(=O)c2cc3c(=O)oc(=O)c3cc12</smiles>

$\mathrm{O}$

$\mathrm{AcOH} / 120^{\circ} \mathrm{C} / 12 \mathrm{~h}$ $65 \%$

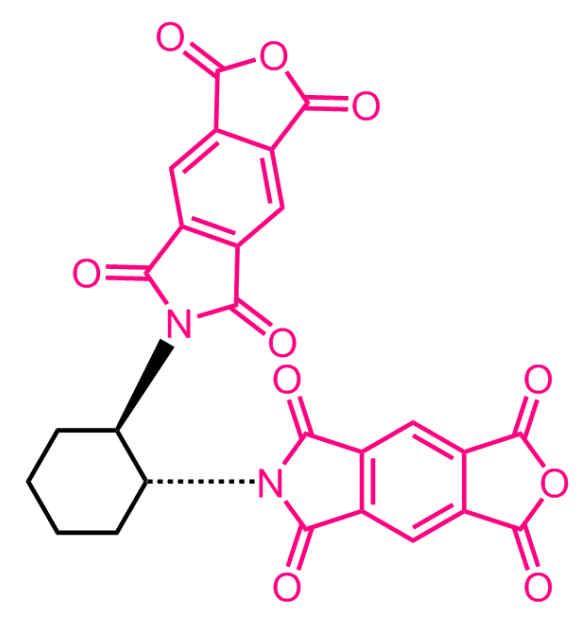

(-)-2PMIA

\section{Scheme S3. Synthesis of (-)-2PMIA}

(-)-2PMIA. A warm solution of $(R R)$-trans-1,2-cyclohexanediamine $(1.87 \mathrm{~g}, 16.4 \mathrm{mmol})$ in glacial $\mathrm{AcOH}(200 \mathrm{~mL})$ was added at $70{ }^{\circ} \mathrm{C}$ to a vigorously stirred solution of pyromellitic dianhydride $(28.6 \mathrm{~g}, 131.0 \mathrm{mmol})$ in glacial $\mathrm{AcOH}(400 \mathrm{~mL})$ under $\mathrm{N}_{2}$. The resulting reaction mixture was then stirred at $120{ }^{\circ} \mathrm{C}$ for $12 \mathrm{~h}$ under $\mathrm{N}_{2}$, after which time the solvent was removed under reduced pressure. The crude residue was dissolved in $\mathrm{CH}_{2} \mathrm{Cl}_{2}$ and subjected to column chromatography $\left(\mathrm{SiO}_{2}: \mathrm{CH}_{2} \mathrm{Cl}_{2} / \mathrm{Me}_{2} \mathrm{CO}\right.$, gradient from 0-10\% $\left.\mathrm{Me}_{2} \mathrm{CO}\right)$ to afford pure (-)-2PMIA $(5.5 \mathrm{~g}, 10.69 \mathrm{mmol})$ in $65 \%$ yield as a white solid. ${ }^{1} \mathrm{H} \mathrm{NMR}\left(500 \mathrm{MHz}, \mathrm{CDCl}_{3}, 25{ }^{\circ} \mathrm{C}\right) \delta=8.33(\mathrm{~s}$, 4H), $5.08-4.98(\mathrm{~m}, 2 \mathrm{H}), 2.60-2.42(\mathrm{~m}, 2 \mathrm{H}), 2.04-1.90(\mathrm{~m}, 4 \mathrm{H}), 1.69-1.46(\mathrm{~m}, 2 \mathrm{H}) .{ }^{13} \mathrm{C} \mathrm{NMR}$ $\left(125 \mathrm{MHz}, \mathrm{CDCl}_{3}, 25^{\circ} \mathrm{C}\right) \delta=165.1,160.5,137.7,136.4,121.0,52.2,29.0,24.9$. MALDI-TOFHRMS $(m / z)$ : calcd for $[M-\mathrm{H}]^{-}=513.058$; found: 513.429 . 


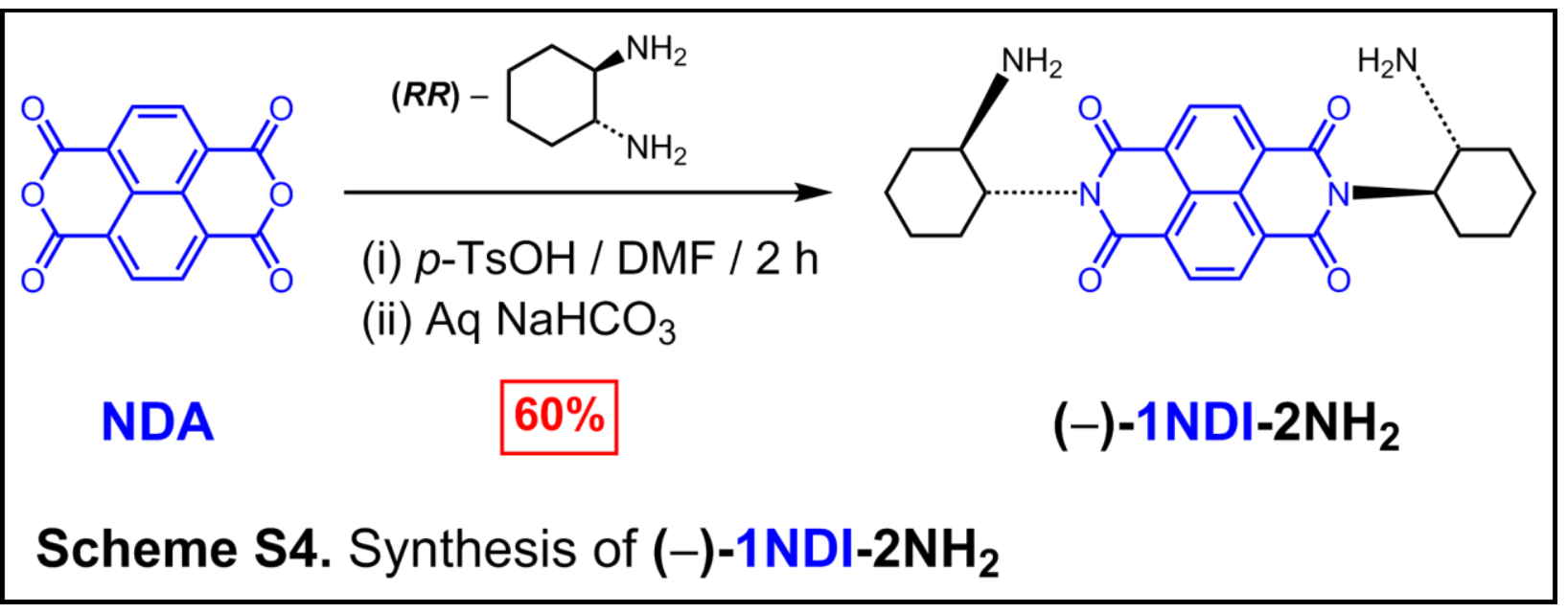

(-)-1NDI-2NH2. The synthetic protocol was adopted ${ }^{12,13}$ according to the literature procedure, except that a slightly modified procedure was used as follows. The compound $(R R)$-trans-1,2cyclohexanediamine $(1.14 \mathrm{~g}, 10.0 \mathrm{mmol})$ was added quickly in one portion to a vigorously stirred suspension of naphthalenetetracarboxylic dianhydride $(1.34 \mathrm{~g}, 5.0 \mathrm{mmol})$ and $p$-toluenesulfonic acid monohydrate $(1.90 \mathrm{~g}, 10.0 \mathrm{mmol})$ in anhydrous DMF $(20 \mathrm{~mL})$ at room temperature. The reaction mixture was stirred at $125^{\circ} \mathrm{C}$ until a homogenous solution was obtained and the stirring was continued for an additional $2 \mathrm{~h}$, after which time the homogenous solution became transformed into a suspension. The reaction mixture was cooled down to room temperature and the solvent was removed under reduced pressure. The crude residue was purified by precipitation, followed by filtration from $\mathrm{MeOH}$-benzene to afford a ditosylate salt of (-)-1NDI-2NH2 as a red solid. This ditosylate of (-)-1NDI-2NH2 was taken up in $\mathrm{CH}_{2} \mathrm{Cl}_{2}(200 \mathrm{~mL})$ and a saturated $\mathrm{NaHCO}_{3}$ solution (50 mL) was added to this $\mathrm{CH}_{2} \mathrm{Cl}_{2}$ solution. The resulting solution was stirred overnight at room temperature. The organic layer was separated and the aqueous layer was extracted with $\mathrm{CH}_{2} \mathrm{Cl}_{2}$ (3 $\times 100 \mathrm{~mL})$. The organic layers were combined, dried $\left(\mathrm{MgSO}_{4}\right)$ and concentrated under reduced pressure to afford pure (-)-1NDI-2NH2 $(1.38 \mathrm{~g}, 3.00 \mathrm{mmol})$ in $60 \%$ overall yield as a pale yellow solid. ${ }^{1} \mathrm{H}$ NMR $\left(500 \mathrm{MHz}, \mathrm{CDCl}_{3}, 25^{\circ} \mathrm{C}\right) \delta=8.72(\mathrm{~s}, 4 \mathrm{H}), 4.90-4.65(\mathrm{~m}, 2 \mathrm{H}), 3.73(\mathrm{td}, J=10.8$, $4.1 \mathrm{~Hz}, 2 \mathrm{H}), 2.62-2.37(\mathrm{~m}, 2 \mathrm{H}), 2.18-2.00(\mathrm{~m}, 2 \mathrm{H}), 1.97-1.67(\mathrm{~m}, 6 \mathrm{H}), 1.58-1.39(\mathrm{~m}, 4 \mathrm{H})$, $1.36-1.21(\mathrm{~m}, 6 \mathrm{H}) .{ }^{13} \mathrm{C}$ NMR $\left(125 \mathrm{MHz}, \mathrm{CDCl}_{3}, 25{ }^{\circ} \mathrm{C}\right) \delta=163.3,131.4,130.8,126.9,61.4$, 50.5, 38.0, 28.9, 26.2, 25.5. ESI-MS $(\mathrm{m} / \mathrm{z})$ : calcd for $[M+\mathrm{H}]^{+}=461.22$; found: 461.22. 


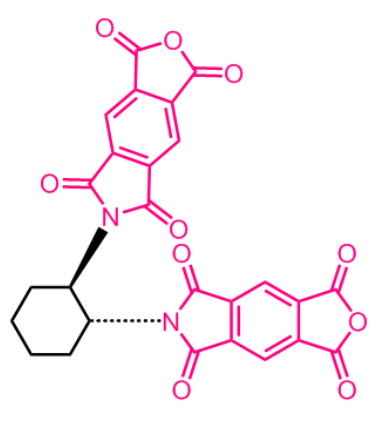

(-)-2PMIA

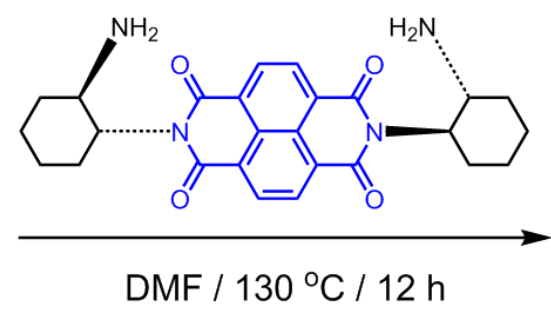

$50 \%$

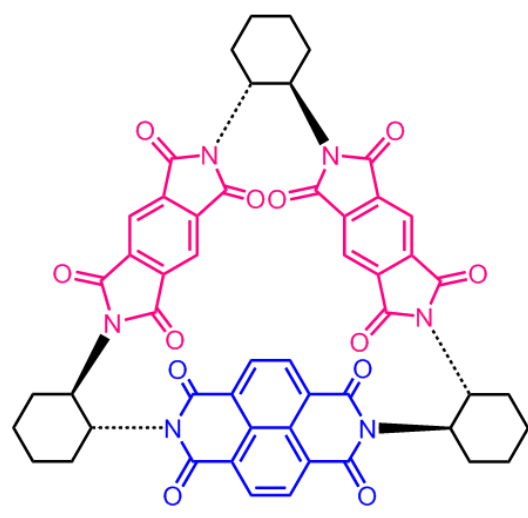

(-)-2PMDI-1NDI- $\Delta$

Scheme S5. Synthesis of (-)-2PMDI-1NDI- $\Delta$

(-)-2PMDI-1NDI- $\Delta$. A warm suspension of (-)-1NDI-2NH2 (0.92 g, $2.0 \mathrm{mmol})$ in anhydrous DMF (30 mL) was added quickly to a vigorously stirred homogenous solution of (-)-2PMIA (1.03 g, $2.0 \mathrm{mmol})$ in anhydrous DMF $(80 \mathrm{~mL})$ at $70{ }^{\circ} \mathrm{C}$ under $\mathrm{N}_{2}$. The resulting reaction mixture was stirred overnight at $130{ }^{\circ} \mathrm{C}$ under $\mathrm{N}_{2}$, after which time the DMF was removed under reduced pressure ( $\sim 3 \mathrm{mbar})$ at $60{ }^{\circ} \mathrm{C}$. The deep red residue was dissolved in $\mathrm{CH}_{2} \mathrm{Cl}_{2}$ and subjected to column chromatography $\left(\mathrm{SiO}_{2}: \mathrm{CH}_{2} \mathrm{Cl}_{2} / \mathrm{Me}_{2} \mathrm{CO}\right.$, gradient from 0-10\% $\left.\mathrm{Me}_{2} \mathrm{CO}\right)$ to afford pure (-)2PMDI-1NDI- $\Delta$ (0.94 g, $1.0 \mathrm{mmol})$ in 50\% yield as an off-white solid. ${ }^{1} \mathrm{H}$ NMR (500 MHz, $\left.\mathrm{CDCl}_{3}, 25^{\circ} \mathrm{C}\right) \delta=8.61(\mathrm{~d}, J=7.7 \mathrm{~Hz}, 2 \mathrm{H}), 8.58(\mathrm{~d}, J=7.7 \mathrm{~Hz}, 2 \mathrm{H}), 7.95(\mathrm{~d}, J=0.9 \mathrm{~Hz}, 2 \mathrm{H}), 7.93$ $(\mathrm{d}, J=0.9 \mathrm{~Hz}, 2 \mathrm{H}), 5.88(\mathrm{td}, J=11.7,3.7 \mathrm{~Hz}, 2 \mathrm{H}), 5.50(\mathrm{td}, J=11.7,3.6 \mathrm{~Hz}, 2 \mathrm{H}), 5.17-5.07(\mathrm{~m}$, 2H), $2.51-2.38(\mathrm{~m}, 2 \mathrm{H}), 2.26-2.14(\mathrm{~m}, 2 \mathrm{H}), 2.09-2.01(\mathrm{~m}, 2 \mathrm{H}), 2.00-1.83(\mathrm{~m}, 12 \mathrm{H}), 1.72-$ $1.60(\mathrm{~m}, 4 \mathrm{H}), 1.60-1.46(\mathrm{~m}, 2 \mathrm{H}) .{ }^{13} \mathrm{C} \mathrm{NMR}\left(125 \mathrm{MHz}, \mathrm{CDCl}_{3}, 25^{\circ} \mathrm{C}\right) \delta=165.9,165.7,165.1$ 162.7, 162.5, 136.6, 136.4, 136.2, 136.1, 131.8, 131.0, 126.6, 126.4, 126.0, 118.8, 54.1, 51.4, 51.3, 31.2, 31.1, 29.7, 25.6, 25.5, 25.1. ESI-HRMS $(\mathrm{m} / \mathrm{z})$ : calcd for $[M+\mathrm{H}]^{+}=939.2620$; found: 939.2607. 


\section{Section C. NMR Spectroscopy}

a)

${ }^{1} \mathrm{H}$ NMR Spectrum of (-)-1PMDI-2NDI- $\Delta$ in CDCl3:
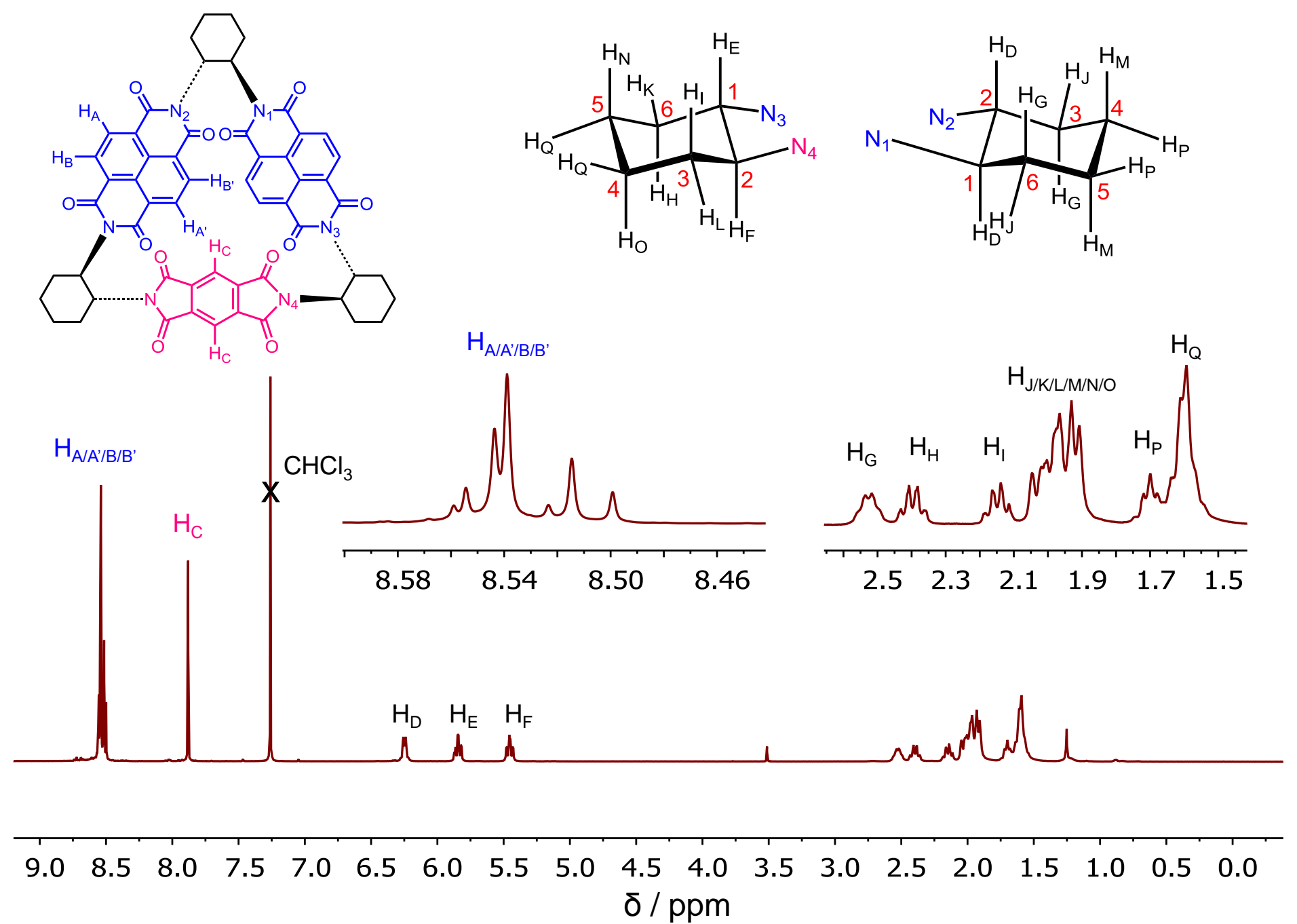

Figure S1. Annotated ${ }^{1} \mathrm{H}$ NMR spectrum (500 MHz, CDCl 33 , $298 \mathrm{~K}$ ) of (-)-1PMDI-2NDI- $\Delta$. 
b) ${ }^{13} \mathrm{C}$ NMR Spectrum of (-)-1PMDI-2NDI- $\Delta$ in $\mathrm{CDCl}_{3}$ :

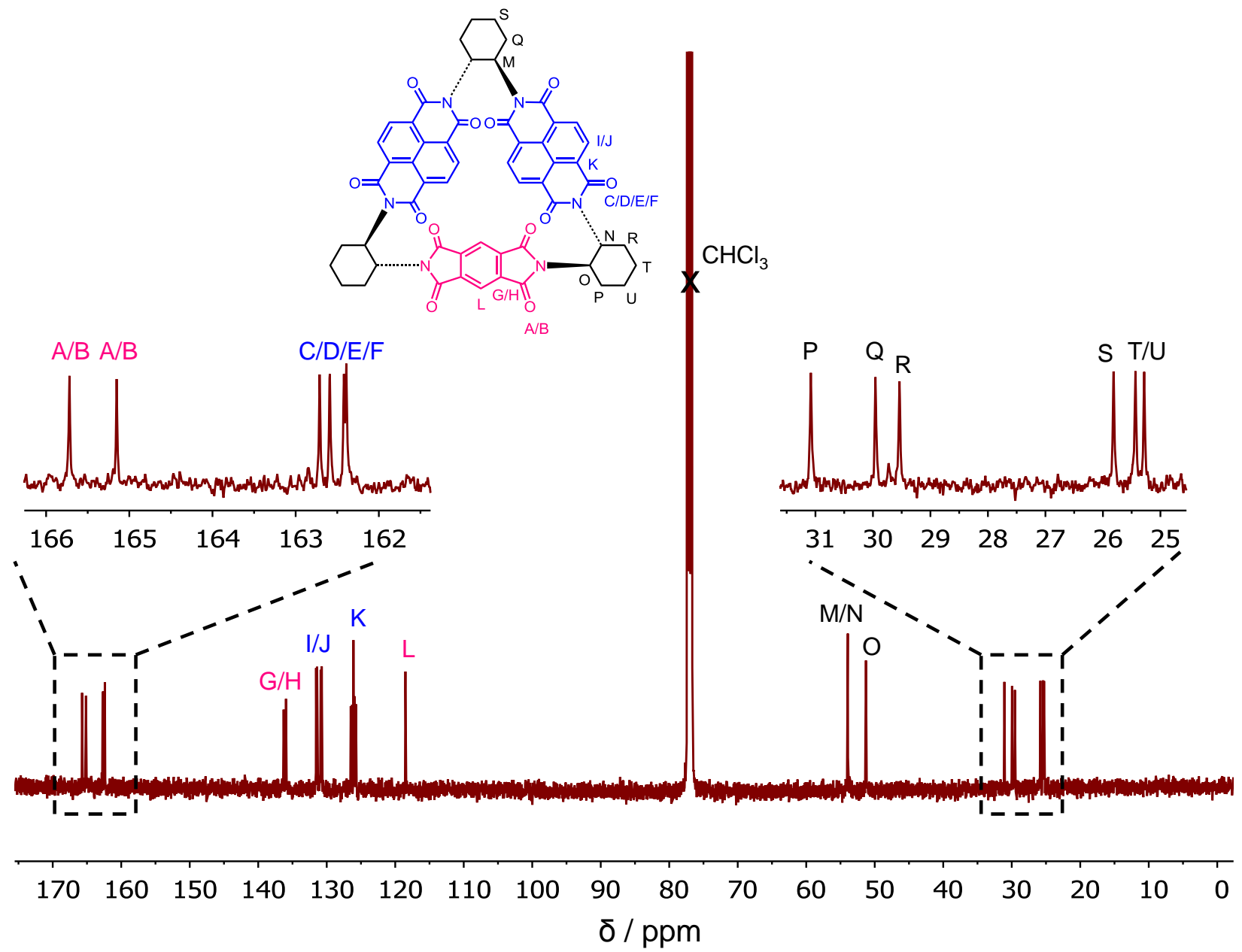

Figure S2. Annotated ${ }^{13} \mathrm{C}$ NMR spectrum (125 MHz, $\left.\mathrm{CDCl}_{3}, 298 \mathrm{~K}\right)$ of (-)-1PMDI-2NDI- $\Delta$.

c) Annotated 2D ${ }^{1} \mathrm{H}-{ }^{1} \mathbf{H}$ Correlation (COSY), Nuclear Overhauser Effect (NOESY), ${ }^{1} \mathrm{H}-$ ${ }^{13}$ C Heteronuclear Single Quantum Coherence (HSQC) and Heteronuclear Multiple Bond Correlation (HMBC) NMR Spectroscopies of (-)-1PMDI-2NDI- $\Delta$ in $\mathrm{CDCl}_{3}$ :

The unambiguous assignment of the various methine $(-\mathrm{CH})$ and methylene $\left(-\mathrm{CH}_{2}\right)$ protons of the triangular macrocycle (-)-1PMDI-2NDI- $\Delta$ was established using 2D Correlation (COSY) and Nuclear Overhauser Effect (NOESY) NMR spectroscopy (Figure S3). The unambiguous assignment of various carbonyl, aromatic and cyclohexano carbons corresponding to the individual 
PMDI and NDI moieties of the triangular macrocycle (-)-1PMDI-2NDI- $\Delta$ was established using 2D ${ }^{1} \mathrm{H}-{ }^{13} \mathrm{C}$ heteronuclear single quantum coherence (HSQC) and heteronuclear multiple bond correlation (HMBC) NMR spectroscopies (Figure S4).

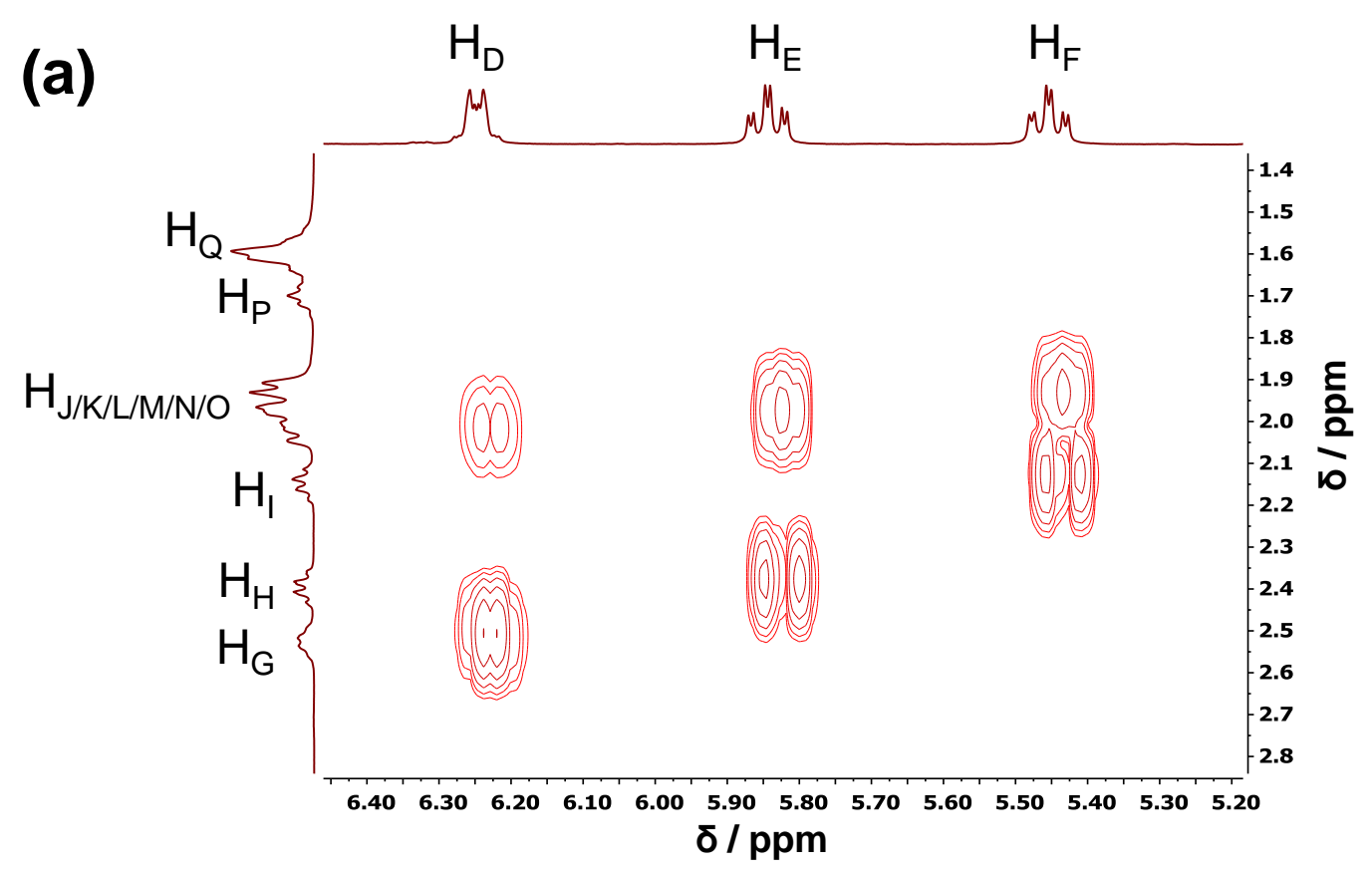

(b)

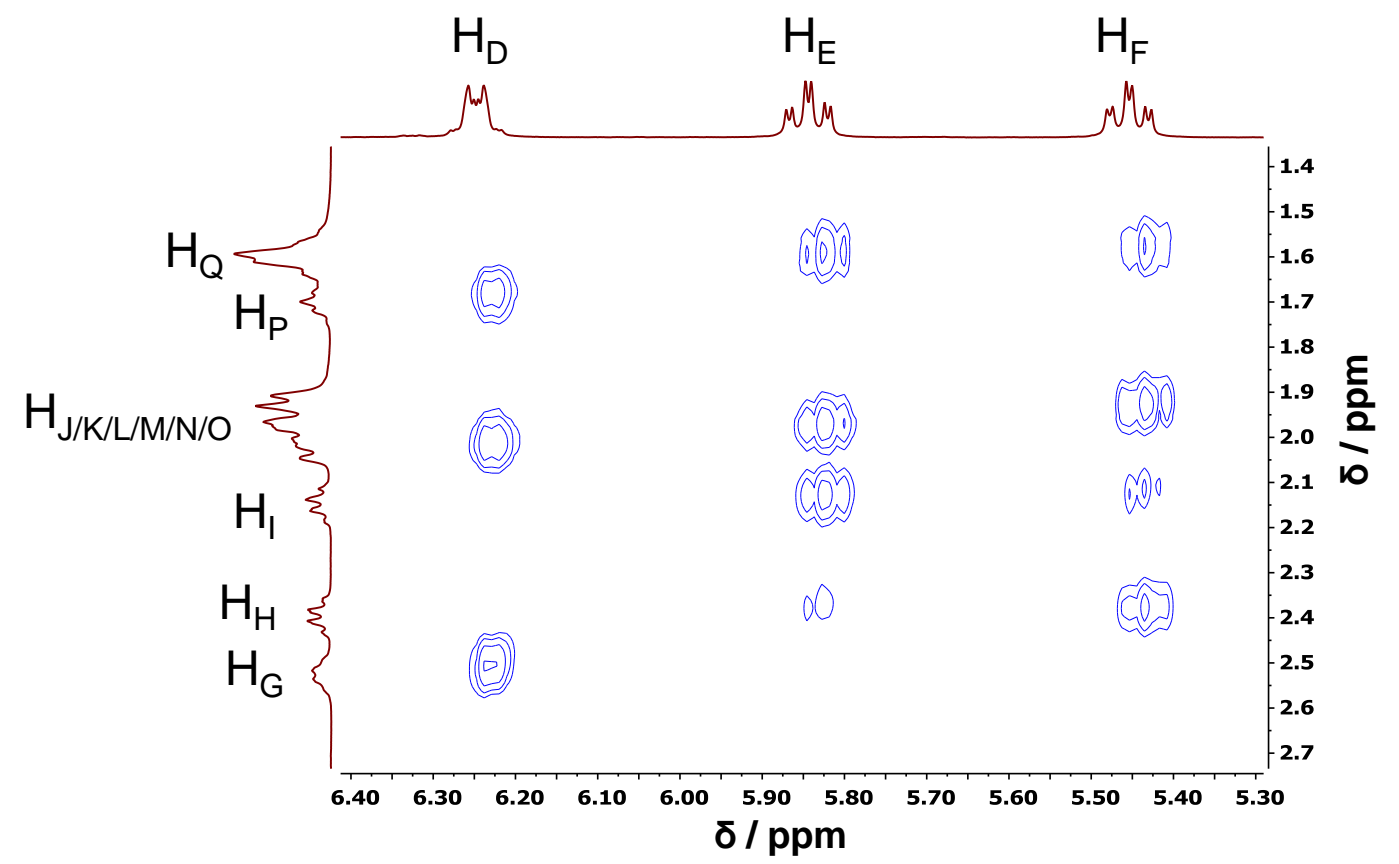

Figure S3. Parts of the annotated 2D ${ }^{1} \mathrm{H}-{ }^{1} \mathrm{H}$ (a) COSY and (b) NOESY NMR spectra (500 MHz, $\left.\mathrm{CDCl}_{3}, 298 \mathrm{~K}\right)$ of (-)-1PMDI-2NDI- $\Delta$. 

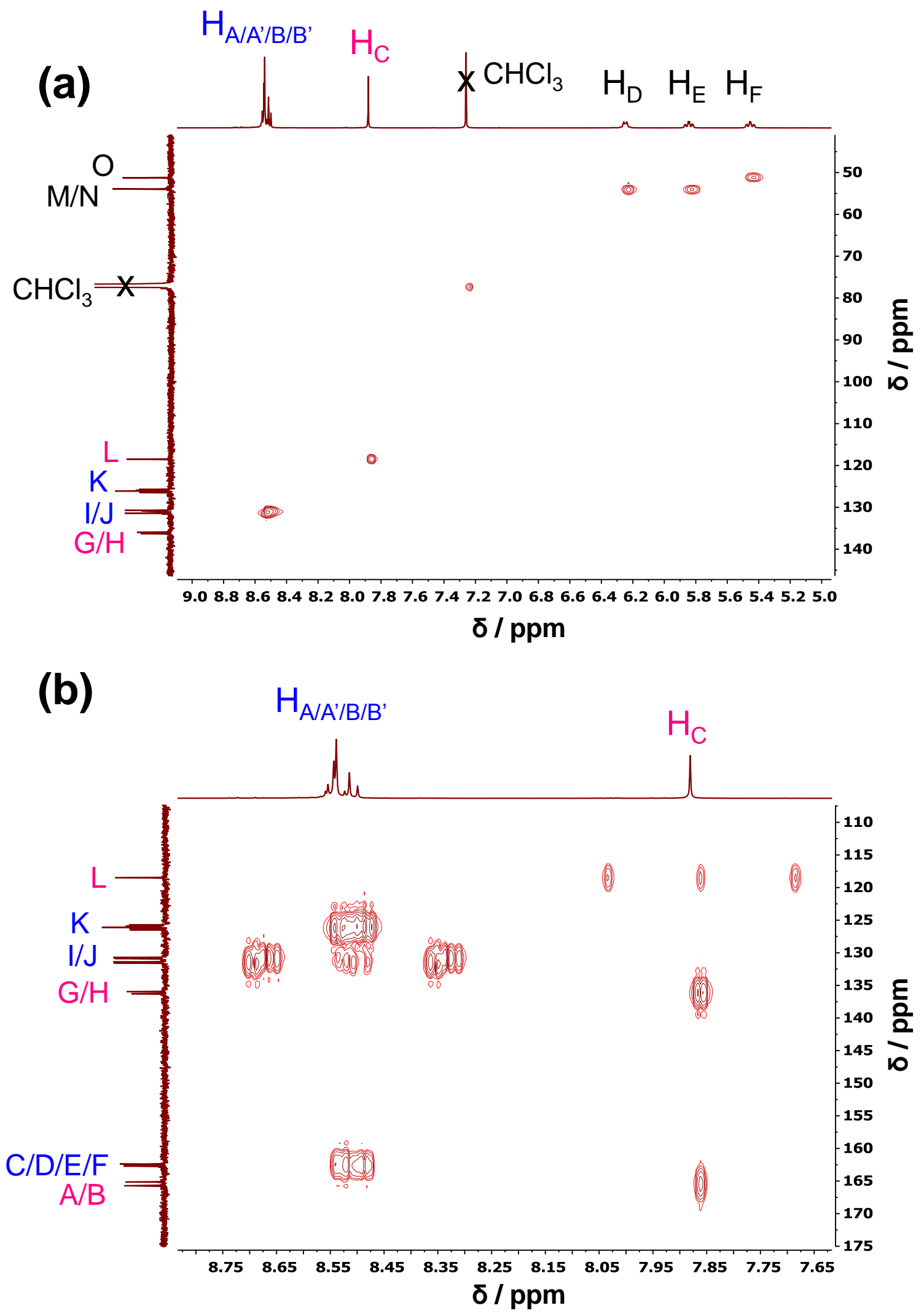

Figure S4. Parts of the annotated $2 \mathrm{D}{ }^{1} \mathrm{H}-{ }^{13} \mathrm{C}$ (a) $\mathrm{HSQC}$ and (b) $\mathrm{HMBC}$ spectra $\left(125 \mathrm{MHz}, \mathrm{CDCl}_{3}\right.$, $298 \mathrm{~K})$ of (-)-1PMDI-2NDI- $\Delta$. 
d) ${ }^{1} \mathrm{H}$ NMR Spectrum of (-)-2PMDI-1NDI- $\Delta$ in $\mathrm{CDCl}_{3}$ :
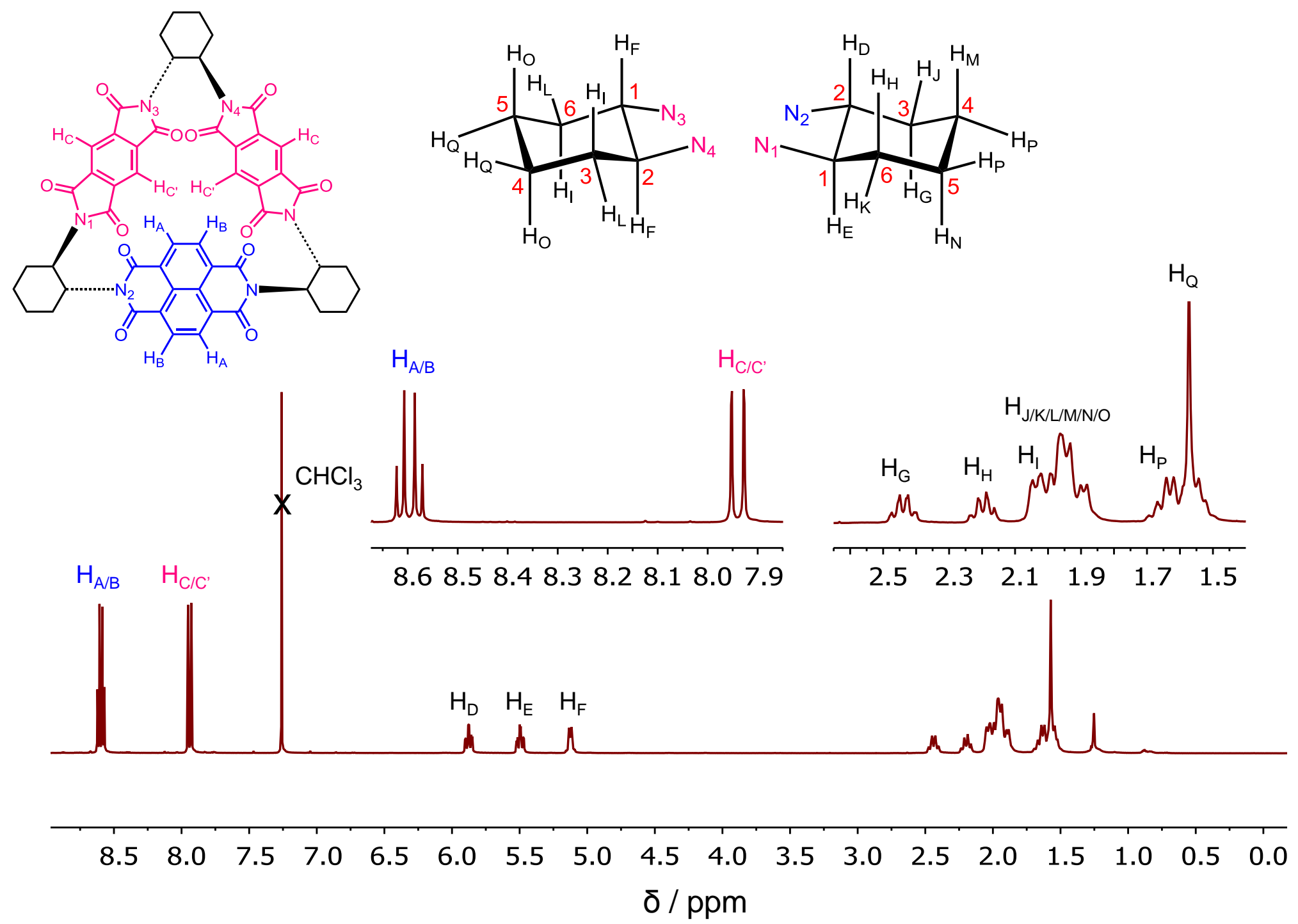

Figure S5. Annotated ${ }^{1} \mathrm{H}$ NMR spectrum (500 MHz, $\mathrm{CDCl}_{3}, 298 \mathrm{~K}$ ) of (-)-2PMDI-1NDI- $\Delta$. 
e) ${ }^{13} \mathrm{C}$ NMR Spectrum of (-)-2PMDI-1NDI- $\Delta$ in $\mathrm{CDCl}_{3}$ :

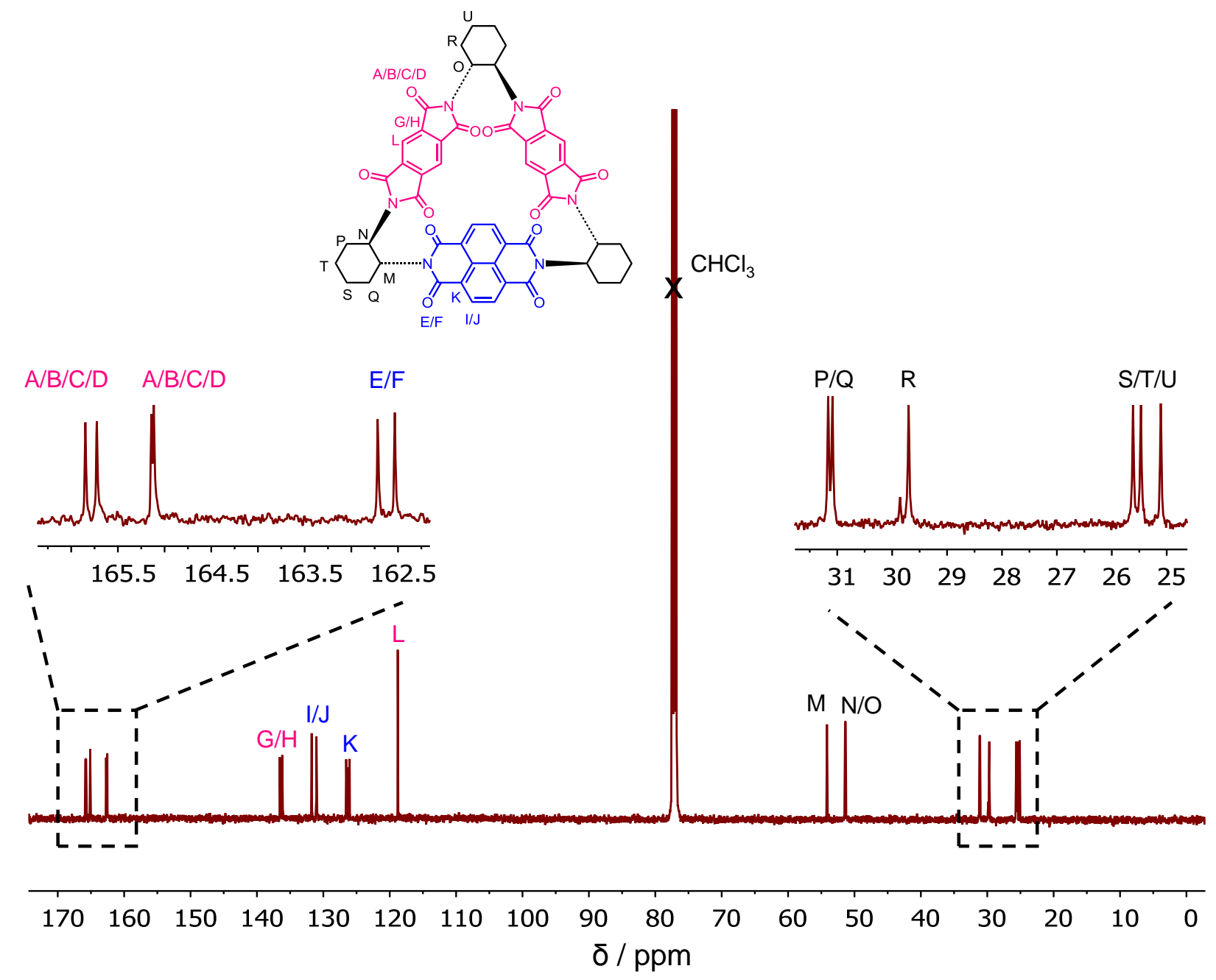

Figure S6. Annotated ${ }^{13} \mathrm{C}$ NMR spectrum $\left(125 \mathrm{MHz}, \mathrm{CDCl}_{3}, 298 \mathrm{~K}\right)$ of (-)-2PMDI-1NDI- $\Delta$.

f) Annotated 2D ${ }^{1} \mathrm{H}-{ }^{1} \mathrm{H}$ Correlation (COSY), Nuclear Overhauser Effect (NOESY), ${ }^{1} \mathrm{H}-$ ${ }^{13}$ C Heteronuclear Single Quantum Coherence (HSQC) and Heteronuclear Multiple Bond Correlation (HMBC) NMR Spectroscopies of (-)-2PMDI-1NDI- $\Delta$ in CDCl3:

The unambiguous assignment of various methine $(-\mathrm{CH})$ and methylene $\left(-\mathrm{CH}_{2}\right)$ protons of the triangular macrocycle (-)-2PMDI-1NDI- $\Delta$ was established using 2D Correlation (COSY) and Nuclear Overhauser Effect (NOESY) NMR spectroscopy (Figure S7). The unambiguous 
assignment of various carbonyl, aromatic and cyclohexano carbons corresponding to the individual PMDI and NDI moieties of the triangular macrocycle (-)-2PMDI-1NDI- $\Delta$ was established using 2D ${ }^{1} \mathrm{H}-{ }^{13} \mathrm{C}$ heteronuclear single quantum coherence (HSQC) and heteronuclear multiple bond correlation (HMBC) NMR spectroscopies (Figure S8).

(a)

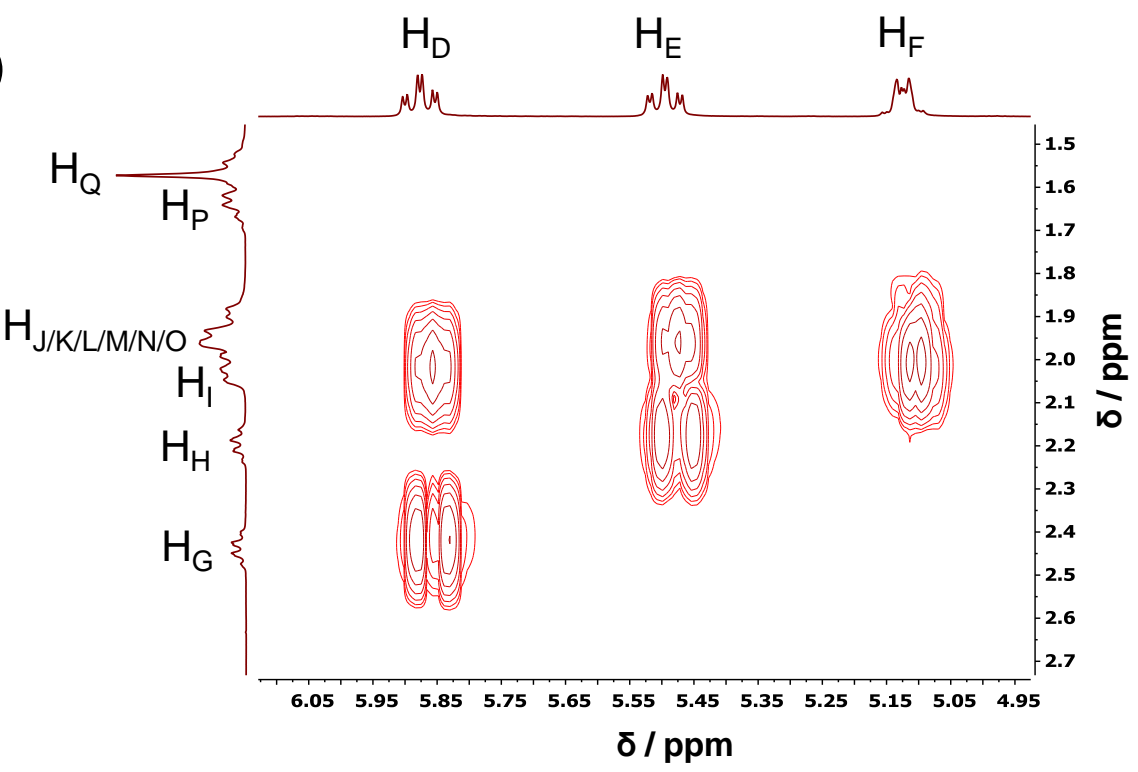

(b)

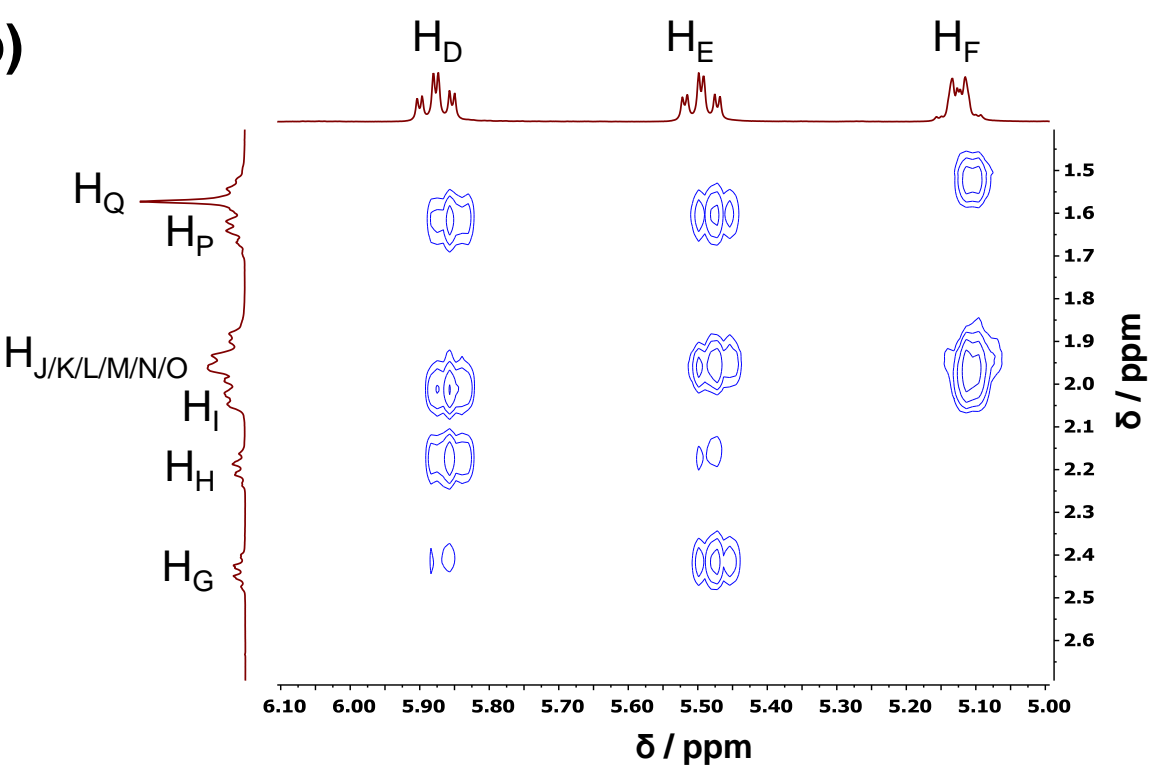

Figure S7. Parts of the annotated $2 \mathrm{D}{ }^{1} \mathrm{H}-{ }^{1} \mathrm{H}$ (a) COSY and (b) NOESY NMR spectra (500 MHz, $\left.\mathrm{CDCl}_{3}, 298 \mathrm{~K}\right)$ of (-)-2PMDI-1NDI-A. 

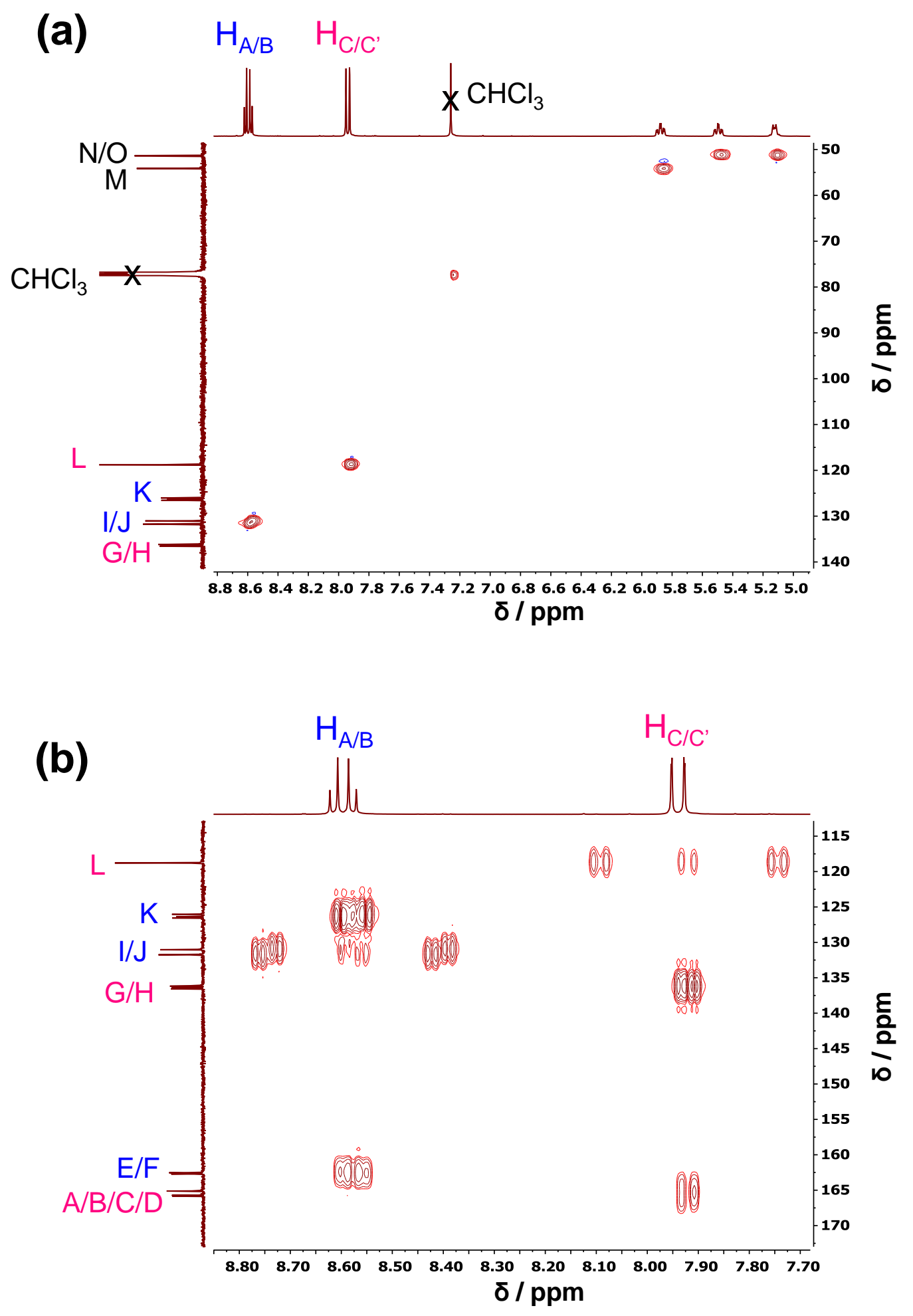

Figure S8. Parts of the annotated $2 \mathrm{D}{ }^{1} \mathrm{H}-{ }^{13} \mathrm{C}$ (a) $\mathrm{HSQC}$ and (b) $\mathrm{HMBC}$ spectra $\left(125 \mathrm{MHz}, \mathrm{CDCl}_{3}\right.$, 298 K) of (-)-2PMDI-1NDI- $\Delta$. 


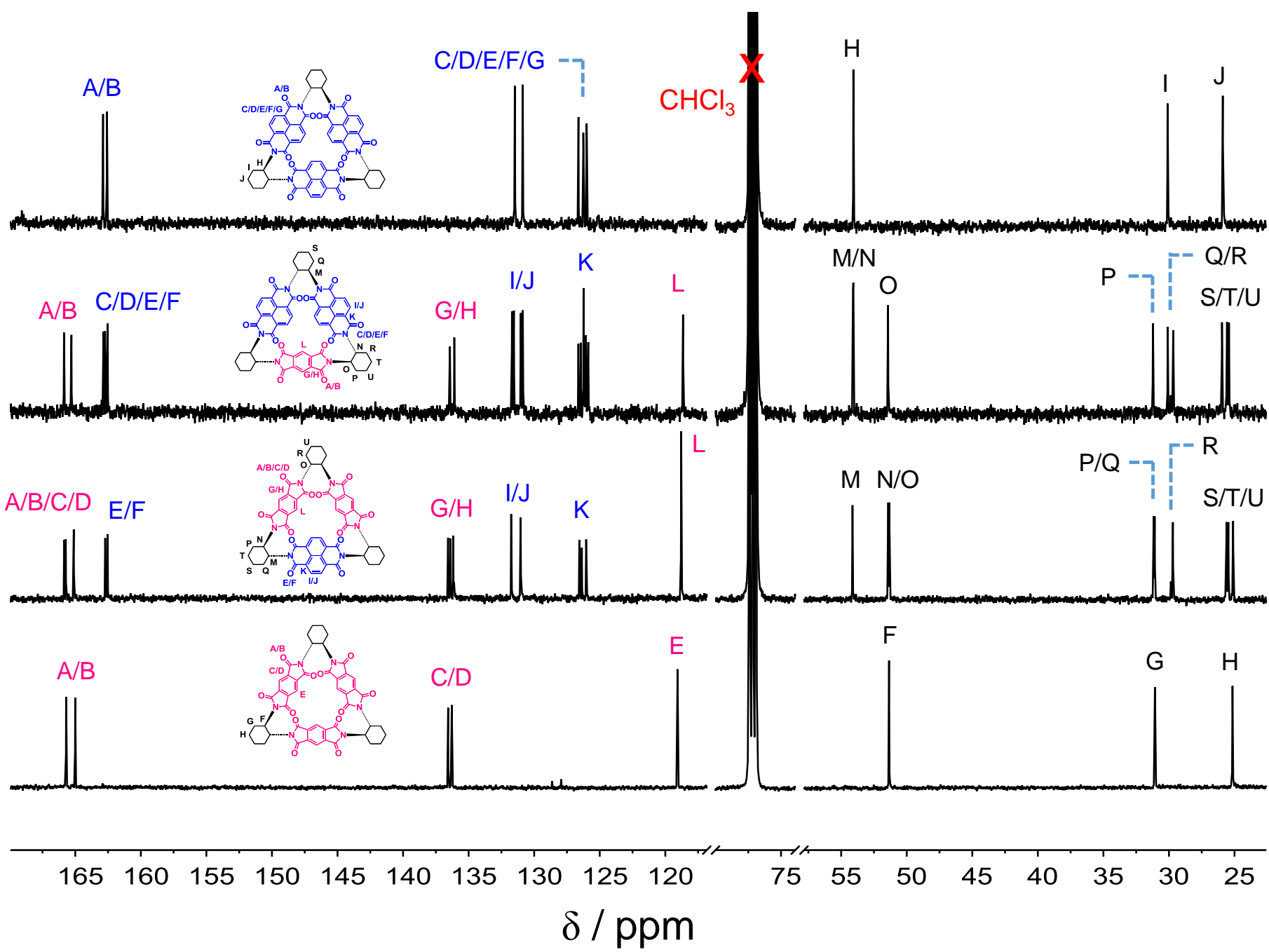

Figure S9. The comparison of the annotated ${ }^{13} \mathrm{C}$ NMR Spectra (125 MHz, $\left.\mathrm{CDCl}_{3}, 298 \mathrm{~K}\right)$ of (-)-3NDI- $\Delta$, (-)-1PMDI-2NDI- $\Delta$, (-)2PMDI-1NDI- $\Delta$ and (-)-3PMDI- $\Delta$ macrocycles. The unambiguous assignment of all the peaks was shown in Figures S2 and S6. 


\section{Section D. Crystallographic Characterization}

\section{1) (-)-1PMDI-2NDI-4}

a) Method: Single crystals of (-)-1PMDI-2NDI- $\Delta$ were grown by slow vapor diffusion of $n$ hexane into a $3.0 \mathrm{mM}$ solution in 1,2-dibromoethane over the course of 3 days. A suitable crystal was selected and mounted in inert oil and transferred to the cold gas stream of a Kappa Apex 2 diffractometer. The crystal was kept at $99.99 \mathrm{~K}$ during data collection. Using Olex $2^{14}$, the structure was solved with the ShelXT ${ }^{15}$ structure solution program using Direct Methods and refined with the ShelXL ${ }^{16}$ refinement package using Least Squares minimization.

b) Crystal Data: orthorhombic, space group $P 2{ }_{1} 2_{1} 2_{1}$ (no. 19), $a=9.2311(4), b=18.4418(7), c=$ $37.1578(14) \AA, V=6325.7(4) \AA^{3}, Z=4, T=99.99 \mathrm{~K}, \mu(\mathrm{CuK \alpha})=6.632 \mathrm{~mm}^{-1}, D_{\text {calc }}=1.828 \mathrm{~g} / \mathrm{mm}^{3}$, 90253 reflections measured $(5.35 \leq 2 \Theta \leq 133.336), 11099$ unique $\left(R_{\text {int }}=0.0720, R_{\text {sigma }}=0.0398\right)$ which were used in all calculations. The final $R_{1}$ was 0.1034 (I $\left.>2 \sigma(\mathrm{I})\right)$ and $\mathrm{w} R_{2}$ was 0.2688 (all data).

c) Refinement Details: Rigid bond restraints were imposed on the displacement parameters as well as restraints on similar amplitudes separated by less than $1.7 \AA$ globally. Distance restraints were imposed on the 1,2-dibromoethane solvent molecules. 


\section{2) (-)-2PMDI-1NDI-A}

a) Method: Single crystals of (-)-2PMDI-1NDI- $\Delta$ were grown by slow vapor diffusion of water into a $5.0 \mathrm{mM}$ solution in DMF over the course of 3 days. A suitable crystal was selected and mounted in inert oil and transferred to the cold gas stream of a Kappa Apex 2 diffractometer. The crystal was kept at $100.02 \mathrm{~K}$ during data collection. Using Olex $2^{14}$, the structure was solved with the ShelXT ${ }^{15}$ structure solution program using Direct Methods and refined with the ShelXL ${ }^{16}$ refinement package using Least Squares minimization.

b) Crystal Data: monoclinic, space group $P 2{ }_{1}$ (no. 4), $a=18.6699(9), b=18.7951(9), c=$ $33.5586(16) \AA, \beta=94.656(2)^{\circ}, V=11736.9(10) \AA^{3}, Z=2, T=100.02 \mathrm{~K}, \mu(\mathrm{CuK} \alpha)=0.755 \mathrm{~mm}^{-1}$, $D_{\text {calc }}=1.249 \mathrm{~g} / \mathrm{mm}^{3}, 120580$ reflections measured $(2.642 \leq 2 \Theta \leq 130.506), 39700$ unique $\left(R_{\text {int }}=\right.$ $\left.0.0614, R_{\text {sigma }}=0.0707\right)$ which were used in all calculations. The final $R_{1}$ was $0.0703(\mathrm{I}>2 \sigma(\mathrm{I}))$ and $\mathrm{w} R_{2}$ was 0.2023 (all data).

c) Refinement Details: The enhanced rigid-bond restraint (SHELX keyword RIGU) was applied on the disordered oxygen atoms. ${ }^{17}$

d) Solvent Treatment Details: The solvent masking procedure as implemented in Olex2 was used to remove the electronic contribution of solvent molecules from the refinement. As the exact solvent content is not known, only the atoms used in the refinement model are reported in the

formula here. Total solvent accessible volume / cell = 1700.6 $\AA^{3}[14.5 \%]$ and Total electron count $/$ cell $=596.7$ 


\section{Section E. Cycling Performance studies of the Batteries}
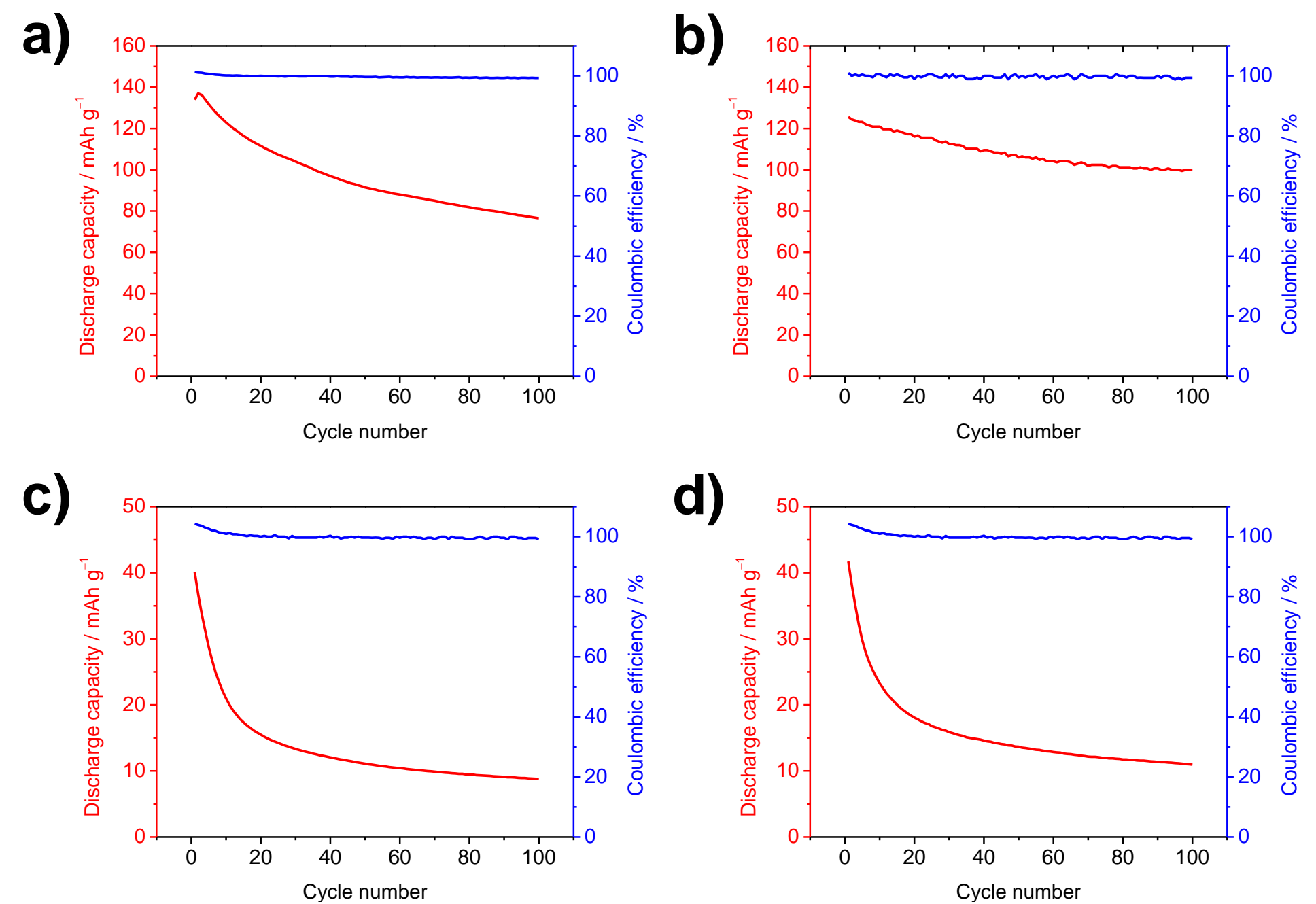

Figure S10. Cycling performance and Coulombic efficiency at rates of a) $0.5 \mathrm{C}$ and b) $1.0 \mathrm{C}$ for the (-)-1PMDI-2NDI- $\Delta$ battery over 100 cycles. Cycling performance and Coulombic efficiency at rates of c) $0.5 \mathrm{C}$ and d) $1.0 \mathrm{C}$ for the (-)-2PMDI-1NDI- $\Delta$ battery over 100 cycles. 


\section{Section F. References}

(1) Schneebeli, S. T.; Frasconi, M.; Liu, Z.; Wu, Y.; Gardner, D. M.; Strutt, N. L.; Cheng, C.; Carmieli, R.; Wasielewski, M. R.; Stoddart, J. F. Angew. Chem., Int. Ed. 2013, 52, 13100.

(2) Gawroński, J.; Brzostowska, M.; Gawrońska, K.; Koput, J.; Rychlewska, U.; Skowronek, P.; Nordén, B. Chem. -Eur. J. 2002, 8, 2484.

(3) Wu, Y.; Nalluri, S. K. M.; Young, R. M.; Krzyaniak, M. D.; Margulies, E. A.; Stoddart, J. F.; Wasielewski, M. R. Angew. Chem., Int. Ed. 2015, 54, 11971.

(4) Shukla, D.; Nelson, S. F.; Freeman, D. C.; Rajeswaran, M.; Ahearn, W. G.; Meyer, D. M.; Carey, J. T. Chem. Mater. 2008, 20, 7486.

(5) Gawroński, J.; Brzostowska, M.; Kacprzak, K.; Kołbon, H.; Skowronek, P. Chirality 2000, 12, 263.

(6) Larrow, J.; Jacobsen, E. Org. Synth. 1998, 75, 1.

(7) The MathWorks, Inc., Natick, MA, USA.

(8) Stoll, S.; Schweiger, A. J. Magn. Reson. 2006, 178, 42.

(9) Hanwell, M. D.; Lutz, K. Abstr. Pap. Am. Chem. Soc. 2012, 244, Abstract 93.

(10) Ufimtsev, I. S.; Martinez, T. J. J. Chem. Theory Comput. 2009, 5, 2619.

(11) Shao, Y.; Molnar, L. F.; Jung, Y.; Kussmann, J.; Ochsenfeld, C.; Brown, S. T.; Gilbert, A. T. B.; Slipchenko, L. V.; Levchenko, S. V.; O'Neill, D. P.; DiStasio Jr, R. A.; Lochan, R. C.; Wang, T.; Beran, G. J. O.; Besley, N. A.; Herbert, J. M.; Yeh Lin, C.; Van Voorhis, T.; Hung Chien, S.; Sodt, A.; Steele, R. P.; Rassolov, V. A.; Maslen, P. E.; Korambath, P. P.; Adamson, R. D.; Austin, B.; Baker, J.; Byrd, E. F. C.; Dachsel, H.; Doerksen, R. J.; Dreuw, A.; Dunietz, B. D.; Dutoi, A. D.; Furlani, T. R.; Gwaltney, S. R.; Heyden, A.; Hirata, S.; Hsu, C.-P.; Kedziora, G.; Khalliulin, R. Z.; Klunzinger, P.; Lee, A. M.; Lee, M. S.; Liang, W.; Lotan, I.; Nair, N.; Peters, B.; Proynov, E. I.; Pieniazek, P. A.; Min Rhee, Y.; Ritchie, J.; Rosta, E.; David Sherrill, C.; Simmonett, A. C.; Subotnik, J. E.; Lee Woodcock Iii, H.; Zhang, W.; Bell, A. T.; Chakraborty, A. K.; Chipman, D. M.; Keil, F. J.; Warshel, A.; Hehre, W. J.; Schaefer Iii, H. F.; Kong, J.; Krylov, A. I.; Gill, P. M. W.; Head-Gordon, M. Phys. Chem. Chem. Phys. 2006, 8, 3172.

(12) Kaik, M.; Gawroński, J. Org. Lett. 2006, 8, 2921.

(13) Kaik, M.; Gawroński, J. Tetrahedron: Asymmetry 2003, 14, 1559.

(14) Dolomanov, O. V.; Bourhis, L. J.; Gildea, R. J.; Howard, J. A. K.; Puschmann, H. J. Appl. Crystallogr. 2009, 42, 339.

(15) Sheldrick, G. Acta. Crystallogr. Sect. A 2015, 71, 3.

(16) Sheldrick, G. Acta. Crystallogr. Sect. A 2008, 64, 112.

(17) Thorn, A.; Dittrich, B.; Sheldrick, G. M. Acta. Crystallogr. Sect. A 2012, 68, 448. 